\title{
RANCANG BANGUN APLIKASI PERBAIKAN OS KOMPUTER DENGAN METODE IMAGE CLONING PADA PT. MIDI UTAMA INDONESIA, TBK MAKASSAR
}

\author{
Rohayati Arifin \\ Program Studi Sistem Informasi, STMIK AKBA, \\ Jalan Perintis Kemerdekaan, Makassar, Indonesia \\ email : rohayatiarifin@akba.ac.id
}

\begin{abstract}
ABSTRAK
Penelitian ini bertujuan untuk membuat suatu aplikasi perbaikan OS komputer yang mudah dan efektif. Metode yang digunakan adalah metode image cloning yang digabungkan dengan metode backup sehingga di dapatkan suatu aplikasi yang dapat digunakan oleh karyawan toko untuk memperbaiki OS komputer yang rusak, sehingga tim IT alfamidi tidak perlu ke lokasi untuk meng-install ulang OS komputer toko yang rusak. Berdasarkan hasil pengujian menggunakan metode black box dan white box, secara fungsional maka tingkat keefektifan dan kemudahan dari persepsi tim IT dan karyawan toko yang diukur melalui pembagian kuesioner mencapai $98 \%$ (sangat baik). Berdasarkan pengujian keefektifan yang dilakukan, aplikasi ini sangat efektif digunakan, karna hanya membutuhkan waktu 1 jam 19 menit untuk memperbaiki OS komputer yang rusak sedangkan dengan cara manual membutuhkan waktu 5 jam 38 menit. Berdasarkan pengujian efisiensi aplikasi ini sangat efisien karena tidak memerlukan biaya sedangkan dengan menggunakan cara manual membutuhkan biaya.
\end{abstract}

Kata Kunci-Cloning, Linux Slax, PT. Midi utama, Tbk, OS komputer.

\begin{abstract}
This study aims to create an easy and effective computer OS repair application. The method used is the image cloning method combined with the backup method. In this study, the author tries to create an application that can be used by store employees to repair a damaged computer OS. So that the Alfamidi IT team does not need to go to the location to reinstall the damaged shop computer OS. Based on the test results using the black box and white box method, it can be concluded that functionally the application is designed to produce the expected results. The level of effectiveness and ease of perceptions of the IT team and store employees as measured by the distribution of the questionnaire reached $98 \%$ (very good). Based on the effectiveness testing carried out, this application is very effective to use, because it only takes 1 hour 19 minutes to repair a damaged computer OS while manually it takes 5 hours 38 minutes. Based on testing the efficiency of this application is very efficient because it does not require money, while using the manual method costs money.
\end{abstract}

Keywords-Cloning, Linux Slax, PT. Midi Utama Indonesia, Tbk, Computer OS repairs 


\section{PENDAHULUAN}

PT. Midi Utama Indonesia, Tbk (Alfamidi) adalah salah satu perusahaan yang bergerak dibidang retail dengan konsep toko moderen (Minimarket). Perusahaan ini memiliki kantor pusat yang berlokasi di Jl. M.H. Thamrin No. 9, Cikokol, Tangerang Indonesia dan mulai beroperasi secara komersial pada bulan Juni 2007. Alfamidi memiliki beberapa cabang yang tersebar di berbagai kota di Indonesia, salah satunya kota Makassar yang berlokasi di jalan. Kima 8 Blok. SS no. 23 Makassar. Sampai dengan bulan Juni 2020 cabang Makassar resmi memiliki 179 gerai toko yang tersebar di berbagai daerah di provinsi Sulawesi Selatan.

Sebagai perusahaan retail yang berkembang, alfamidi menggunakan sistem operasi (OS) komputer dalam melakukan pelayanan. Dalam penggunaan komputer, biasa terjadi kerusakan, sehingga tim IT harus ke lokasi untuk memperbaiki (instal ulang komputer). Oleh sebab itu diperlukan sebuah sistem yang dapat digunakan oleh karyawan toko untuk melakukan perbaikan ketika terjadi kerusakan komputer, sehingga tim IT tidak perlu lagi ke lokasi. Apalagi jarak geografis kabupaten atau kota di Sulawesi Selatan tergolong jauh seperti Bulukumba $153 \mathrm{~km}$, Sinjai $220 \mathrm{~km}$, Bone $174 \mathrm{~km}$, Soppeng 192 km, Wajo $242 \mathrm{~km}$, Sidrap $188 \mathrm{~km}$, Masamba 326, Malili $565 \mathrm{~km}$, Rantepao $328 \mathrm{~km}$ (Badan Pusat Statistika Sulawesi Selatan 2013). Dengan jarak yang begitu jauh, sangat tidak efektif dan efisien jika setiap ada OS komputer yang rusak tim IT harus ke lokasi. Oleh karena itu diperlukan sebuah sistem untuk memudahkan penanganan kerusakan OS komputer yang jauh.

Ada beberapa penelitian sebelumnya yang dapat digunakan untuk memperbaiki OS komputer yang rusak yaitu penelitian yang dilakukan oleh Yulia, dkk (2016), dengan judul Rancangan Disaster Recovery Pada Instansi Pendidikan Studi Kasus Universitas Mercu Buana. Penelitian yang dilakukan adalah merancang sistem recovery databases untuk mengantisipasi adanya kehilangan dan kerusakan data akibat bencana atau kegagalan sistem, dengan menggunakan sistem backup databases mirroring dan failover.

Penelitian yang dilakukan oleh Supriyanto, dkk (2019), dengan metode backup yang berjudul Penyusunan Disaster Recovery Plan (DRP) berdasarkan Framework NIST SP 800-34 (Studi Kasus: Departemen Teknologi Informasi PT Pupuk Kalimantan Timur). Penelitian yang dilakukan adalah penyusunan rencana backup data dan recovery pada keseluruhan sistem dan aplikasi pada PT Pupuk Kaltim dengan berpedoman pada NIST SP 800-34. Pada penelitian ini backup dan recovery dilakukan berdasarkan prioritas dan prosedur pemulihan. Prosedur yang dilakukan dibagi menjadi tiga yaitu prosedur pemulihan untuk layanan berbasis web, prosedur pemulihan layanan berbasis desktop, dan prosedur pemulihan layanan berbasis network.
Tujuan dari penelitian ini adalah untuk menyediakan file recovery bila terjadi kehilangan atau kerusakan data yang diakibatkan oleh bencana agar dapat tetap beroperasi setelah terjadinya bencana.

Penelitian yang dilakukan oleh Haryadi, dkk (2019), dengan judul Implementasi Sistem Backup Perusahaan Sebagai Bagian dari Disaster Recovery Plan. Penelitian tersebut menggunakan sofware VMware dengan framework Network Development Life Cycle (NDLC) yang digunakan untuk mengantisipasi jika

terjadi kehilangan atau kerusakan data. VMware akan mem-backup setiap data yang ditentukan dan dapat memberikan notifikasi melalui email jika diperlukan. Penggunaan software VMware pada penelitian ini berpedoman pada framework (NDLC).

Penelitian sebelumnya hanya menggunakan backup sebagai pencadangan data, file dan databases, dengan tujuan data yang dicadangkan dapat dikembalikan ketika terjadi kehilangan atau kerusakan data. Maka dari itu peneliti tertarik untuk melakukan penelitian backup OS komputer menggunakan metode image cloning untuk mengatasi permasalahan pada PT. Midi Utama Indonesia, Tbk.

Berdasarkan latar belakang yang telah uraikan, peneliti tertarik untuk menciptakan suatu produk berupa aplikasi Perbaikan OS komputer yang akan digunakan pada PT. Midi Utama Indonesia, Tbk. Peneliti tertarik untuk melakukan penelitian yang berjudul Rancang Bangun Aplikasi Perbaikan OS Komputer Dengan Metode Image Cloning Pada PT. Midi Utama Indonesia, Tbk Makassar.

\section{TINJAUAN PUSTAKA}

\subsection{Pengertian Sistem Operasi}

Sistem operasi merupakan perangkat lunak (sofware) yang bertugas sebagai pengatur sumber daya komputer dan berfungsi sebagai antarmuka pada perangkat komputer (Andy 2019). Menurut Lubis dan Sembiring (2018), sistem operasi merupakan penghubung antara perangkat keras komputer dengan pengguna komputer.

\subsection{Pengertian Cloning}

Cloning hard disk merupakan metode atau teknik yang digunakan untuk meng-copy program komputer atau file-file komputer yang berukuran besar secara mudah ke Hard disk komputer lain(Rida 2015). Proses ini merupakan proses penyalinan secara langsung, bit demi bit sehingga sama persis dengan data yang disalin .Semua status attribut dan lokasi akan berlaku identik dan sama persis. Proses cloning selalu berpasangan dengan restore yaitu proses yang digunakan untuk mengembalikan data image cloning ke hard disk sebelumnya.

\subsection{Pengertian Backup}


Menurut Andry (2017), backup merupakan sebuah proses pengamanan data ke media yang lain dengan cara penduplikasian. Yang bertujuan sebagai data cadangan apabila terjadi kehilangan data atau kerusakan data.

\subsection{Metode Extream Programming (XP)}

Metode Extreame Programing (XP) merupakan metode perancangan perangkatb lunak yang dicetus oleh Kent Beck, seorang pakar software engineering. Metode ini merupakan metode pengembangan sistem yang efisien yang menyederhanakan berbagai tahapan pada perancangan sistem(Fatoni dan Dwi 2016).

\subsection{Java}

Java merupakan bahasa pemrograman berorientasi object yang dapat dijalankan diberbagai platform dan merupakan bahasa tingkat tinggi (Rizki Sari Dewi 2020). Salah satu kelebihan dari java adalah dapat dijalankan diberbagai platform serta gratis. Namun dari kelebihan tersebut java juga memiliki kekurangan seperti penggunaan memori yang cukup besar dan muda di decompilasi.

\subsection{Konsep pemodelan sistem}

Unified Modeling Language (UML) adalah bahasa yang digunakan untuk menjelaskan dan menerangkan perangkat lunak yang dikembangkan ke user(Suendri 2018). UML bahasa yang digunakan untuk menggambarkan dan menjelaskan program yang akan dibuat dalam bentuk gambar atau grafik kepada user.

\section{METODOLOGI PENELITIAN}

\subsection{Metode Analisis}

Dalam memetakan kelayakan sistem maka di lakukan analisis menggunakan SWOT dengan tahapan sebagai berikut:

1. Kekuatan (Strenght)

a. Diterapkan sebagai system aplikasi yang mudah digunakan

b. Sebagai teknologi yang dapat digunakan mempercepat penanganan perbaikan OS computer.

c. Dapat digunakan oleh karyawan took walaupun tidak memiliki pengetahuan mengenai komputer.

2. Kelemahan (Weakness)

a. Membutuhkan storage yang besar.

b. Membutuhkan SDM yang ahli dalam instalasi

3. Peluang (Opportunity)

a. Penanganan kerusakan OS komputer dapat dilakukan oleh karyawan toko sendiri.

b. Tim IT tidak perlu ke took untuk untuk install ulang system operasi computer yang rusak

4. Ancaman (Threats)

a. Ketersedian hard disk.

b. Faktor kemalasan membuat file image backup.

\subsection{Metode Perancangan Sistem}

Metode yang digunakan dalam perancangan aplikasi ini adalah Extreme Programming $(X)$, dengan tahap-tahap sebagai berikut :

1. Studi Literatur

Melakukan studi literature pada buku, skripsi, jurnal dan media onli e yangmembahas tentang aplikasi yang ingin dibuat.

2. Pengumpulan Data

Pengumpulan data dilakukan dengan cara wawancara pada tim IT dan karyawan took untuk mengetahui kendala cagannmasalah yang dialami oleh karyawan toko dan tim IT dalam pekerjaannya.

3. Rancang Bangun Aplikasi

a. Perancangan (Planning)

Planning merupakan pencarian solusi dari permasalahan yang diperoleh dari hasil wawancara tim IT dan karyawan toko.

b. Perancangan (Design)

Perancangan tampilan yang dialur program dan diwakili dengan UML.

c. Pengkoean (Coding)

Pembuatan program sesuai dengan perancangan dan desain yang telah di buat sebelumnya.

d. Pengujian (Testing)

Pengujian aplikasi yang dilakukan sesuai kebutuhan pengguna.

e. Release

Memberikan hasil software kepada tim IT untuk dievaluasi apakahtelah selesai dengan kebutuhan.

\subsection{Pengujian Aplikasi}

Pengujian aplikasi ini menggunakan pengujian White box testing dan Black Box Testing. Pengujian ini meliputi pengujian pada algoritma program dengan menggunakan white box testing dan pengujian program berdasarkan fungsional yang ada dari setiap bagian di dalam system yang dibuat, tanpa mengetahui bait program yang ada dengan black box testing.

\subsection{Perancangan Proses}

\subsubsection{Perancangan proses cloning}


Jurnal Ilmiah Ilmu Komputer Vol. 5, No. 1, April 2019 Fakultas Ilmu Komputer

Universitas AL Asyariah Mandar

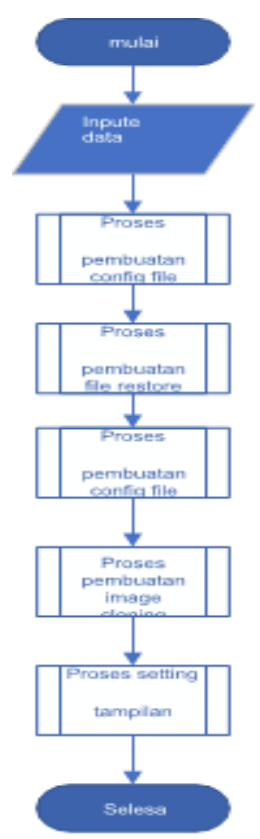

Gambar 1. Flowchart proses cloning

3.3.2. Perancangan proses restore

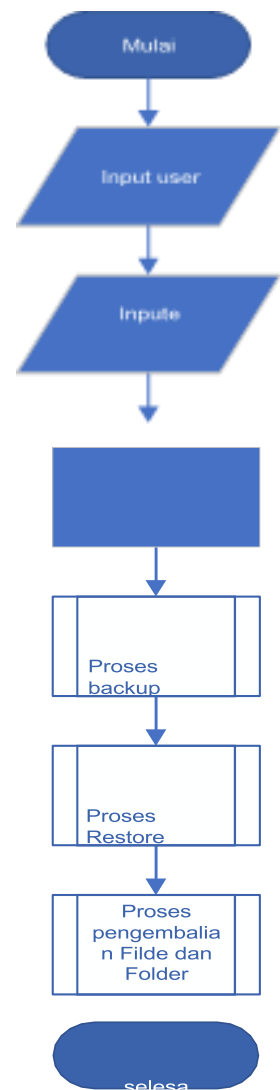

Gambar 2. Flowchart proses restore

3.3.3. Interface antar muka
(P) ISSN 2442-451X

(O) ISSN 2503-3832

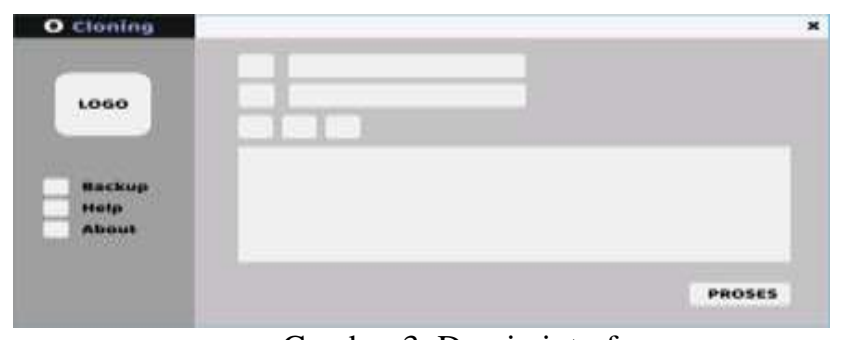

Gambar 3. Desain interface

\section{HASIL DAN PEMBAHASAN}

\subsection{Hasil}

Pada tahap ini dilakukan proses pengkodean dari aplikasi perbaikan OS komputer dengan mengimplementasikan hasil pada tahap planning dan desain yang telah dibuat sebelumnya. Pengkodean yang dilakukan menggunakan bahasa pemrograman java menggunakan Netbeans, yang akan menghasilkan aplikasi perbaikan OS komputer yang akan dijalankan pada linux slax

\subsection{Pengujian system}

Pengujian pada tahap ini, hanya dilakukan oleh peneliti. karena pengujian ini hanya untuk memastikan bahwa linux slax dapat menjalankan aplikasi perbaikan OS komputer yang telah dibuat, pengujian ini langsung dilakukan pada komputer toko.

\subsection{Pengujian program}

Pengujian program di lakukan dengan menggunakan metode whitebox dan blackbox. Pengujian dengan whitebox testing di lakukan oleh peneliti sendiri untuk memastikan apakah alur logika program telah berjalan sesuai dengan yang di harapkan. Selanjutnya pengujian dengan blackbox testing dilakukan oleh programmer dan user pengguna untuk memastikan setiap tombol, input, dan output berjalan dengan baik sesuai dengan yang di harapkan.

\subsection{Manual program}

1. Menu untuk memilih booting OS

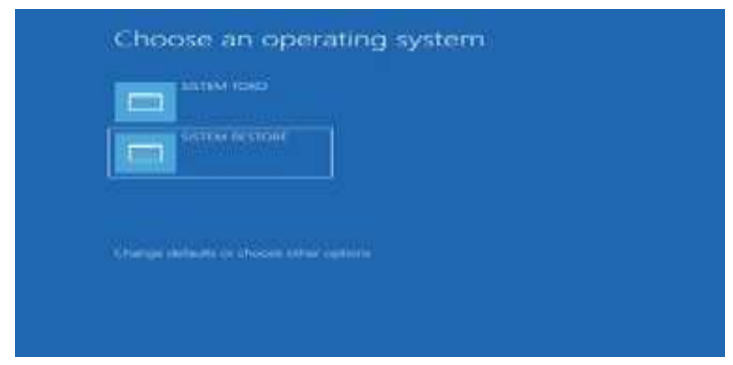

Gambar 4. Menu Booting

2. Tombol memilih partisi windows yang akan di backup 
Jurnal Ilmiah Ilmu Komputer Vol. 5, No. 1, April 2019

Fakultas Ilmu Komputer

Universitas AL Asyariah Mandar

Tombol ini berfungsi untuk mencari partisi windows yang akan di-backup dapat dilihat pada gambar 5 .
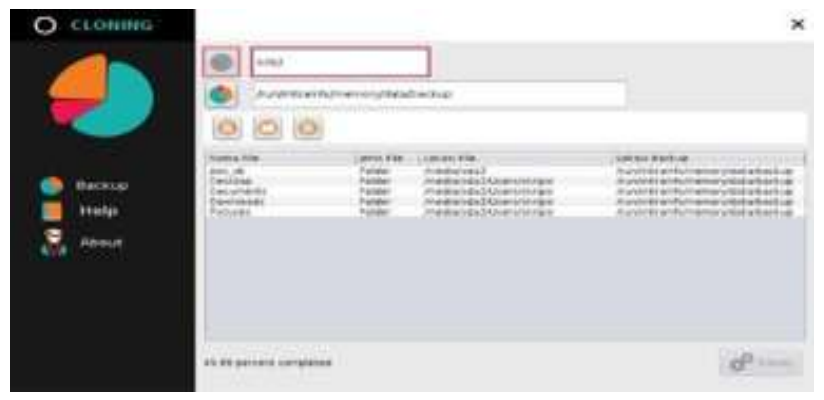

Gambar 5. Pilih partisi windows

3. Tombol untuk menentuka tempat penyimpanan file image backup

Tombol ini berfungsi untuk mencari lokasi tempat penyimpanan file backup dan file image cloning dapat dilihat pada gambar 6

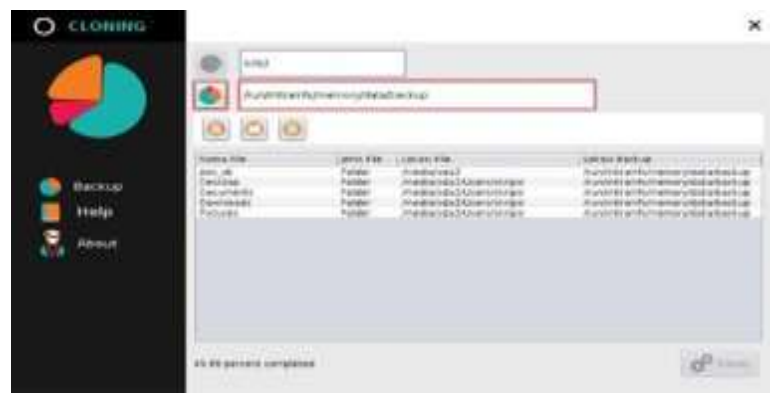

Gambar 6. Tombol save file

4. Tombol untuk memilih file yang akan di backup Tombol ini berfungsi untuk mencari file yang akan dibackup dan akan menampilkan keterangan ketika disorot dengan mouse, dapat dilihat pada gambar 7

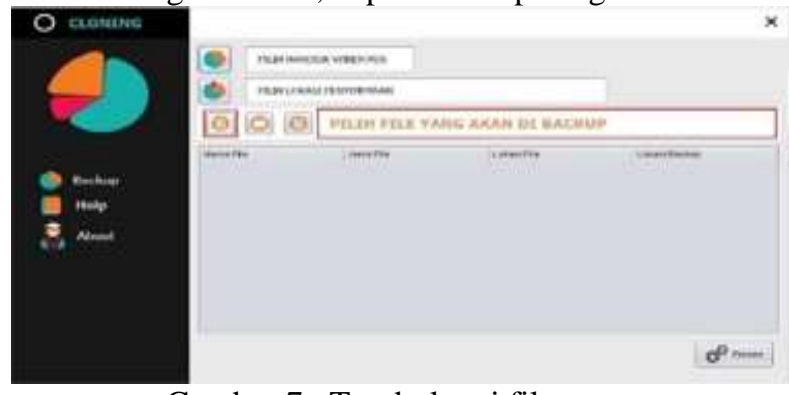

Gambar 7. Tombol cari file

5. Tombol jalankan proses cloning

Tombol proses berfungsi untuk membuat file configurasi backup, menjalankan proses cloning, update tampilan GUI, dan restart sistem setelah proses cloning selesai, dapat dilihat pada gambar 8
(P) ISSN 2442-451X

(O) ISSN 2503-3832

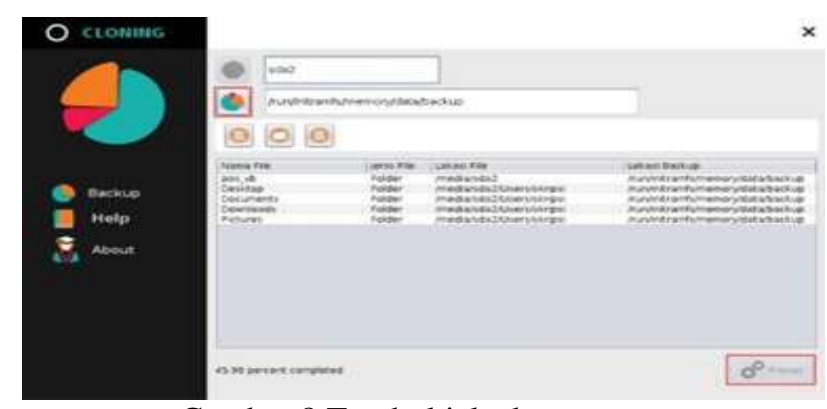

Gambar 8.Tombol jalankan program

\section{KESIMPULAN}

Berdasarkan hasil implementasi dan pengujian aplikasi perbaikan OS komputer menggunakan metode cloning, maka dapat disimpulkan sebagai berikut:

Rancang bangun aplikasi perbaikan OS komputer tanpa menggunakan flash disk atau hard disk dapat dibuat dengan menggunakan linux slax. Pengimplementasian backup pada metode cloning dapat dilakukan dengan menambahkan proses backup sebelum proses restore image cloning dilakukan, yang dilanjutkan dengan proses restore backup, setelah proses restore image cloning selesai.

\section{Daftar Pustaka}

[1] Andry, Johanes Fernandes. 2017. "Pengembangan Aplikasi Backup Dan Restore Secara Automatisasi Menggunakan Sdlc Untuk Mencegah Bencana.” Jurnal Muara Sains, Teknologi, Kedokteran dan Ilmu Kesehatan 1.

[2] Arrosyidi, Achmad. 2017. Uji Durasi Komparasi Lima Sofware Restorasi Sistem Operasi.

[3] Fatoni, Ahmad dan Dhany Dwi. 2016. "Rancang Bangun Sistem Extreme Programming Sebagai Metodologi Pengembangan Sistem.” Prosisko 3(1):14.

[4] Haryadi, Eko, Abdussomad, dan Robi. 2019. "Implementasi Sistem Backup Data Perusahaan Sebagai Bagian dari Disaster Recovery Plan.” sains dan teknoligi 29(2):6-11.

[5] Lubis, Juanda Hakim dan Zulfikar Sembiring. 2018. "Pelatihan Instalasi Komputer, Cloning Sistem Operasi, Serta Membuat File Sharing Pada Jaringan Komputer." Jurnal Prodiknas Hasil Pengabdian Masyarakat 2(1):65-70.

[6] Netbeans. 2020. "Selamat datang di NetBeans dan www.netbeans.org, Wadah dari IDE Java Kode Terbuka." Diambil 11 April 2020 (https://netbeans.org/index_id.html).

[7] Rida, Angga. 2015. "Tips Cara Cloning Hardisk dengan Mudah » Skemaku.com." www.skemaku.com. Diambil 27 Juni 2020 (https://skemaku.com/tips-caracloning-hardisk-dengan-mudah/). 